\title{
The Role of Processing Trade and FDI in China's Economic Growth
}

\author{
Xi-jun WANG \\ School of Economics \\ Xuzhou University of Technology \\ Xuzhou, China
}

\begin{abstract}
Based on VAR mode and using Granger causality test approach and variance decomposition, this article examines the role of processing trade and foreign direct investment (FDI) in China's economic growth, and gives an empirical analysis and test of the dynamic correlation between FDI and processing trade. The empirical result shows that the rapid growth of China's economy has attracted a large amount of FDI and promoted the rapid growth of processing trade. There is a long-term equilibrium relationship between FDI and processing, and the variables influence each other through long-run equilibrium relationship. In the short term, FDI and processing trade will not be significantly affected by long-run equilibrium relationship, while economic growth will be significantly affected by long-turn equilibrium relationship.
\end{abstract}

Keywords-Processing trade; FDI; Granger causality test; VAR

\section{INTRODUCTION}

Foreign direct investment (FDI) not only brought the capital that developing countries badly needed, but also brought advanced technology and management experience. Processing trade is a form of trade characterized by processing. It is a business activity in which the host country imports all or part of the raw and auxiliary materials and intermediate products from overseas bonded, and after processing and assembling by domestic enterprises, the finished products are re-exported, including incoming material processing and incoming material processing. Since reform and opening, China, with its rich resources, cheap labor and a series of preferential policies for foreign investment, has attracted a large number of foreign businessmen to invest direct in China. And at the same time, with the Advancement of international trade and investment liberalization, the reduction of international information costs and transportation costs, the transfer of industries across borders has been promoted, and the processing of some products has been deployed to low-cost countries. China's processing trade has also been developing rapidly. Processing trade has gradually replaced the general trade, becoming China's main trade pattern, which has been playing the pivotal role in promoting industrial structure adjustment and improvement, improving trade structure, stimulating processing technologies and increasing employment opportunities. It has already become the main content and form of China's opening. Then, is there a relationship between FDI, processing trade and economic growth? If so, what kind of relationship would it be? The relationship between FDI and processing trade, the relationship between FDI and economic growth, and the relationship between processing trade and economic growth have been discussed and studied extensively by scholars home and abroad. However, studies on the relationship between FDI, processing trade and economic growth are rare. Therefore, the empirical study on the relationship between FDI, processing trade and China's economic growth has a strong practical significance.

\section{LITERATURE REVIEW}

FDI and processing trade are important phenomena of economic globalization, being one of the most active areas of the world's economic activities, and scholars home and abroad have done a lot of research on it. The term "processing trade" is unique to our country. There is no concept of "processing trade" in foreign countries, but foreign scholars have conducted a lot of research on "export processing zones". Export processing zones are actually the main regions for processing trade (World Bank, 1992). Therefore, foreign research on export processing zones can be regarded as a study of processing trade in a sense. As the status of processing trade in the developed countries is not significant, therefore, foreign research on processing trade is comparatively less. Western scholars mainly do research on processing trade from export processing zones and trade within industry. And domestic research on processing trade mainly focuses on the relationship between processing trade and economic growth, and the research on the relationship between processing trade and FDI is relatively not enough. The study of Zhang Xiaodi and $\mathrm{Li}$ Xiaozhong(2002)[1] shows that the higher the proportion of processing trade is, the lower the marginal effects on GDP from import trade will be; the empirical analysis of Liu Zhizhong and Wang Yaozhong (2003) [2] shows that processing trade's contribution to economic growth is rather low and stimulating degree is relatively low; the empirical result of Yan Guoqing and Chen Lijing(2005)[3] demonstrates that whenever China's processing trade increases by $1 \%$, GDP will increase by $0.761 \%$, and the degree of processing trade's contribution equals 53\%; Sun Churen, Shen Yuliang, Zhao Hongjun (2006) [4] calculates the overall contribution of processing trade import and other trade import to economic growth is negative; Yang Songli and Yu Haishan (2006) [5] make an empirical analysis of processing trade's effect on Zhejiang's economic growth by comprehensively employing processing trade value-added factor, the promoting degree of processing trade to Zhejiang's GDP and other analyzing method such as linear regression; Wang Yong and Zhao Bo(2006) [6] , by employing Co-integration theory, verified that there exists a long-term dynamic equilibrium relationship 
between processing trade and China's economic growth; Zhu Qirong (2007) [7], by employing linear regression approach, draws the conclusion that the increase of general trade import and export and the processing trade export both impulse the increase of GDP, while the increase of processing trade import will cause negative growth of GDP; Kong Qingfeng and $\mathrm{Li}$ Xiue (2008) [8], by using Co-integration theory and Granger causality test, make an empirical analysis of the relationship between processing trade and Shandong's economic growth.

Little research has been done on the relationship between FDI and processing trade. Sun Churen, Shen Yuliang and Zhao Hongjun(2008) [9] , by applying panel data of 28 cities and provinces from China between 1993 and 2003, set up a processing trade and FDI integration model to analyze the relationship between processing trade and FDI.

From the above research results, the past research is mainly based on one of the two variables in the above three variables, and there are fewer studies linking the three factors, and the results of the research may lead to one-sided results. Therefore, it is necessary to test and analyze the system of the three components.

\section{BUILDING MODEL AND EMPIRICAL ANALYSIS}

\section{A. Data and Variables}

The samples used for the paper analysis all come from annual data from 1991 to 2016, and the data are all from China Statistical Yearbook of every year. Here, FDI stands for foreign direct investment, PT stands for processing trade, and GDP stands for economic growth. In order to eliminate the effects of inflation, CPI index is used to amend FDI, PT and GDP; to eliminate the existence of heteroskedasticity in time series, variables are all through natural logarithm transformation, listed as $\operatorname{lnFDI}, \ln \mathrm{PT}$ and $\operatorname{lnGDP}$. Their corresponding firstorder difference orders are $\Delta \operatorname{lnFDI}, \Delta \ln \mathrm{PT}$, and $\Delta \operatorname{lnGDP}$. All data will be manipulated on a computer by means of software EViews 5.1.

\section{B. Unit Root Test}

It can be seen from the figure of trends of variable lnFDI, lnGDP and $\ln \mathrm{PT}$ that three variables tend to be rising steadily as time varies, that is, time series is non-stationary. As for the time-series data generated in non-stable processes, traditional mathematical statistics and econometrics methods seem powerless. Modern econometrics, besides using autocorrelation analysis diagram of the series, more formally has a statistical test to judge stationary of time series. Unit root test is one of the statistical tests that are universally applied. This approach judges the stationary of a certain time series through judging whether it has unit root. More often used unit root test techniques include DF approach, ADF approach and PP approach. This paper, by employing ADF [10] approach, gives a stationary test of time series. The main test results are shown in Table I.

TABLE I UNIT ROOT TEST

\begin{tabular}{|c|c|c|c|}
\hline Variable & ADF & Critical value & Conclusion \\
\hline $\ln F D I$ & -2.922 & $-3.255^{* * *}$ & reject null \\
\hline$\Delta \ln F D I$ & -2.769 & $-2.669^{*}$ & cannot reject \\
\hline $\ln P T$ & -0.202 & $-3.255^{* * *}$ & reject null \\
\hline$\Delta \ln P T$ & -1.947 & $-1.608^{* * *}$ & cannot reject \\
\hline $\ln G D P$ & -3.877 & $-4.441^{*}$ & reject null \\
\hline$\Delta \ln G D P$ & -4.231 & $-3.788^{*}$ & cannot reject \\
\hline \multicolumn{2}{|c|}{ Notes: $\Delta$ stands for first difference; *** and ***in the above table respectively stands for the unit root test under the significance level of $1 \%, 5 \%$ and $10 \%$. }
\end{tabular}

It is shown from the test results that logarithmic series of $\operatorname{lnFDI}, \operatorname{lnGDP}$ and $\operatorname{lnPT}$ are all nonstationary, but after the first difference, they are stationary. It is obvious that these three series all belong to first order integration I (1).

\section{Granger Causality Test}

We have Granger causality test of FDI and processing trade. In regression analysis, regression can measure the degree of connection between variables, but can not prove causality. Granger causality test can be applied to have a test of both long-term and short-term cause and effect relationship. Granger causality test was put forward by Granger (1969) and Sims (1972), with its basic idea that the predictive validity of the variable $\mathrm{Y}$ under the condition of including the past information of the variables $\mathrm{X}$ and $\mathrm{Y}$ is superior to that of only considering the past information of $\mathrm{Y}$, that is, the variable $\mathrm{X}$ helps to explain $\mathrm{Y}$ 's future variation, so $\mathrm{X}$ is the Granger causality of $\mathrm{Y}$, or else it is called non-Granger-causality.

According to AIC, we make it certain that the lags of each variable are 1 . Granger causality test results of each variable are shown in Table II.

It is known from Table II that under the significance level of $5 \%, \ln P T$ does Granger cause $\ln F D I$, and $\ln F D I$ does Granger cause $\ln P T$. This indicates that $\ln P T$ and $\ln F D I$ constitute a significant bilateral causality. Processing trade affects FDI, and FDI affects processing trade. There is a unilateral Granger causality between FDI and GDP from GDP to FDI. There is a unilateral Granger causality between PT and GDP from GDP to PT. 
TABLE II GRANGER CAUSALITY TEST

\begin{tabular}{|c|c|c|c|}
\hline Null Hypothesis & Obs & F-Statistic & Probability \\
\hline LNPT does not Granger Cause LNFDI & 25 & 7.35194 & 0.02241 \\
\hline LNFDI does not Granger Cause LNPT & 25 & 5.22582 & 0.04497 \\
\hline LNGDP does not Granger Cause LNFDI & 25 & 5.99477 & 0.03417 \\
\hline LNFDI does not Granger Cause LNGDP & 25 & 1.65893 & 0.29755 \\
\hline LNGDP does not Granger Cause LNPT & 25 & 14.1706 & 0.00528 \\
\hline LNPT does not Granger Cause LNGDP & 25 & 2.53301 & 0.16337 \\
\hline
\end{tabular}

\section{Building and Estimating VAR Model}

VAR model is a kind of modeling idea doing research on the dynamic relationship among multivariable. It builds the model with each endogenous variable in the examined economic system considered to be the lagged value's function of all the endogenous variables in the system, without any restrictions beforehand. To regard each variable as endogenous variable can avoid the problem of regression of the lagged item for every endogenous variable of the system in structure modeling approach. It is an unstructured multi-equation model. Thereafter, this model can be used to make an analysis of the shock on variant system from relevant time series and random perturbation, and further makes an explanation of various economic shocks causing the formation of economic variant.

Firstly, we define the lag order $p$ of VAR model. The paper takes LR, FRE, HQ, AIC and SC into consideration to measure and select the best lag term, thus setting up VAR Model (4). The specific test results are shown in Table III.

TABLE III DEFINITION OF THE LAG ORDER p IN VAR MODEL

\begin{tabular}{|c|c|c|c|c|c|c|}
\hline Lag & LogL & LR & FRE & AIC & SC & HQ \\
\hline 0 & -41.25 & NA & 0.26 & 4.33 & 4.43 & 4.35 \\
\hline 1 & 13.59 & 93.24 & 0.002 & -0.76 & -0.46 & -0.70 \\
\hline 2 & 20.35 & $10.13^{*}$ & $0.001^{*}$ & $-1.04^{*}$ & $-0.54^{*}$ & $-0.94^{*}$ \\
\hline 3 & 22.35 & 2.61 & 0.002 & -0.84 & -0.14 & -0.70 \\
\hline 4 & 28.30 & 6.54 & 0.001 & -1.03 & -0.13 & -0.86 \\
\hline
\end{tabular}

Notes: (1)* indicates lag order selected by the criterion; (2) LR stands for sequential modified LR test statistic (each test at 5\% level); FRE stands for final prediction error; AIC stands for Akaike information criterion; SC stands for Schwarz information criterion; HQ stands for Hannan-Quinn information criterion.

Secondly, build VAR (2) Model with $\ln P T$ and $\ln F D I$ regarded as endogenous variables simultaneously. processing trade is mainly affected by its own fluctuation, the influence by FDI is comparatively weak.

$$
\begin{gathered}
\ln P T_{t}=1.035 \ln P T_{t-1}-0.074 \ln P T_{t-2} \\
-0.004 \ln F D I_{t-1}-0.014 \ln F D I_{t-2}+0.593 \\
R^{2}=0.985 A d j-R^{2}=0.982 \\
F=281.888 \quad A I C=-0.868, S C=-0.620
\end{gathered}
$$

\section{E. Variance Decomposition}

Variance decomposition is to decompose the system's mean square error and analyze the contribution degree of each structure impact on the alteration of endogenous variable. The contribution rate between FDI and processing trade is shown in Table IV.

From tables of variance decomposition, we can see from the 1 st period to the 5 th period, FDI is comparatively greatly affected by processing trade, but tends to be stable after the 11th period; the influence on FDI by its own fluctuation is comparatively small, but gradually increases after the 5th period, and after the 11th period it tends to be stable; 
TABLE IV CONTRIBUTION RATE BETWEEN FDI AND PROCESSING TRADE

\begin{tabular}{|c|c|c|c|c|}
\hline \multirow{2}{*}{ Period } & \multicolumn{2}{|c|}{ Variance decomposition of $\ln F D I$} & \multicolumn{2}{|c|}{ Variance decomposition of $\ln P T$} \\
\hline & $\ln F D I$ & $\ln P T$ & $\ln P T$ & $\ln F D I$ \\
\hline 1 & 0.06 & 99.94 & 100.00 & 0.00 \\
\hline 2 & 0.49 & 99.51 & 100.00 & 0.00 \\
\hline 3 & 0.38 & 99.62 & 99.97 & 0.03 \\
\hline 4 & 0.61 & 99.39 & 99.86 & 0.14 \\
\hline 5 & 2.76 & 97.24 & 99.69 & 0.31 \\
\hline 6 & 7.65 & 92.35 & 99.47 & 0.53 \\
\hline 7 & 14.04 & 85.96 & 99.28 & 0.72 \\
\hline 8 & 19.83 & 80.17 & 99.12 & 0.88 \\
\hline 9 & 24.10 & 75.90 & 99.02 & 0.98 \\
\hline 10 & 27.00 & 73.00 & 98.96 & 1.04 \\
\hline 11 & 28.93 & 71.07 & 98.94 & 1.06 \\
\hline 12 & 30.21 & 69.79 & 98.93 & 1.07 \\
\hline 13 & 31.06 & 68.94 & 98.94 & 1.06 \\
\hline 14 & 31.64 & 68.36 & 98.94 & 1.06 \\
\hline 15 & 32.08 & 67.92 & 98.95 & 1.05 \\
\hline
\end{tabular}

\section{CONCLUSION}

This paper, on the basis of VAR model, by applying Granger causality test, impulse response function and variance decomposition, makes an empirical analysis of the relationship between FDI, processing trade and economic growth. The conclusions of the study are as follows:

The rapid growth of the China's economy has attracted a large amount of FDI and promoted the rapid growth of processing trade.

There exists bilateral Granger causality between processing trade and FDI, which means that processing trade affects FDI, and FDI also affects processing trade. There is a unilateral Granger causality between FDI and GDP from GDP to FDI, which means that the continuous rapid growth of China's economy has attracted a large inflow of FDI. There is a unilateral Granger causality between PT and GDP from GDP to PT, which means that economic growth promotes the development of processing trade.

In the long run, there exists significantly stable relationship between processing trade and FDI. In the short term, the volatility of FDI is affected by processing trade. Over time, the impact of processing trade on FDI volatility has gradually stabilized. The volatility of processing trade is less affected by foreign direct investment.

\section{REFERENCES}

[1] Zhang Xiaodi and Li Xiaozhong, "The Comparative Analysis on Three Trade Model of Three Strong Provinces of Foreign Trade in China." Management World, No. 12, 2002, pp. 40-47.(In Chinese)

[2] Liu Zhizhong and Wang Yaozhong, "An empirial study on contribution of processing trade to economic growth." The Theory and Practice of Finance and Economics, Vol. 24, No. 6, 2003, pp. 89-92.(In Chinese)

[3] Yan Guoqing and Chen Lijing, "Empirical studies of the effect of processing trade on China's economic augment." International Economics and Trade Research, Vo1. 21 No. 2, 2005, pp. 69-72. (In Chinese)

[4] Sun Churen, Shen Yuliang and Zhao Hongjun, "Estimation of contribution of OEM and other trades to economic growth." World Economy Study, No.3, 2006, pp. 54-62. (In Chinese)

[5] Yang Songli and Yu Haishan, "Real example analysis of the economic growth function of processing trade in Zhejiang." Pioneering with Science \& Technology Monthly, No.1, 2006, pp. 106-107. (In Chinese)

[6] Wang Yong and Zhao Bo,"Processing Trade and China's Economic Growth." Practice in Foreign Economic Relations and Trade, No.5, 2006 pp. 24-25. (In Chinese)

[7] Zhu Qirong, "A positive analysis of the influence of conventional trade and processing trade on China's GDP." Shandong Economiy, Vol. 138, No. 1, 2006, pp. 5-7.(In Chinese)

[8] Kong Qingfeng and $\mathrm{Li}$ Xiue, "An Empirical Research of the Relationship between Processing Trade and Economic Growth: A Case of Shangdong Province." Journal of Business Economics, Vo1. 195, No. 1, 2008, pp. 64-68. (In Chinese)

[9] Sun Churen, Shen Yuliang and Zhao Hongjun, "The Relationship between FDI and Processing Trade in China: Substitution, Complement or Else." Nankai Economic Studies, No. 3, 2008, pp. 84-103 . (In Chinese)

[10] D. A. Dickey and W. A. Fuller, "Distribution of the estimators for autoregressive time series with a unit root." Journal of American Statistical Association, Vol. 74, 1979, pp. 427-431. 